\title{
CORRIGENDUM
}

\section{Ageing causes cytoplasmic retention of MaxiK channels in rat corporal smooth muscle cells}

\author{
KP Davies, Y Stanevsky, MT Tar, JS Chang, MR Chance and A Melman
}

International Journal of Impotence Research (2007) 19, 439; doi:10.1038/sj.ijir.3901550

Correction to: International Journal of Impotence Research (2007) 19, 371-377. doi:10.1038/sj.ijir. 3901541
Following the online publication of the above article, the authors noted an error in one of the author names. The complete and correct author names are above. 